\title{
Investigation of the effective factors on rate of stemflow for tree species in Hyrcanian forests
}

\author{
Mehran Nasiri *, Nastaran Zare \& Hamid Jalilvand \\ Department of Forestry, Faculty of Natural Resources, Sari Agricultural Sciences and Natural Resources \\ University, PO Box 737, Sari, Iran
}

\begin{abstract}
The objective of this study was (i) to compare the amount of stemflow in deciduous broadleaved trees (with and without leaves) in accordance with different growth seasons and (ii) to compare the rate of stemflow in coniferous and broadleaved trees in according to the canopy cover area. Stemflow was measured on 20 marked trees using a stemflow collector. Rates were different for the different tree species Beech Fagus orientalis L, Ironwood Parrotia persica L., Alder Alnus subcordata L. and Hornbeam Carpinus betulus L., and were greater in autumn than winter even though trees were then in leaf. The stemflow increased with increasing canopy cover area. Even though canopy cover in conifers (Cupressus sempervirens var. horizontalis) was less than the broad-leaved beech, the rate of stemflow was higher, up to 7 litres per hour with relatively small canopies.
\end{abstract}

Keywords: canopy, seasons, conifers, broad-leaved trees

\section{Introduction}

The Hyrcanian zone is a humid zone in the north of Iran (Ebrahimpour et al. 2011). The average annual rainfall ranges between $530 \mathrm{~mm}$ in the east and $1350 \mathrm{~mm}$ in the west, occasionally reaching up to $2000 \mathrm{~mm}$. Based on climatic data from meteorological stations, the maximum annual rainfall is experienced during spring, and late autumn - winter. Most people shelter under the trees during rainfall because the tree foliage prevents raindrops from reaching the ground. Leaf-water or interception is defined as a part of rainfall water which is absorbed by plant cover. The amount of interception depends on the type of vegetation cover (coniferous or broadleaved), leaf area index, age of forest stands, the garnish of leaves on the tree and the type of rainfall. Values from coniferous forests are higher than those from broadleaved forests, and old and dense forests have higher values than thinned and young forests (Mohajer 2007).

The amount of interception during rainfall of short duration is high, while it is low during rainfall of long duration. The amount of rain caught in coniferous forests (Picea sp.) is 20 to 80 percent and in broadleaves forest (beech) is 10 to 50 percent, in the latter on average $5 \%$ less in winter than in summer because of the lack of leaves on the trees in winter (Helvey $\&$ Patric 1965). Continuous rainfall causes water to saturate tree foliage, and then additional water is conducted to the ground via the stem of trees. The stemflow is defined as the amount of water which moves as flow from foliage to stem and down to the ground. Throughfall is defined as the amount of rainfall which comes through the leaf canopy via the empty spaces between the leaves to the ground (Alizadeh 2007). Thus when it rains, some water is lost as water vapour, while the rest reaches the ground either directly (throughfall) or indirectly (stemflow) (Hanchi \& Rapp 1997).

Morphological differences among trees have been quantified to explain stemflow variability. During precipitation, the morphology and distribution of trees and, collectively the forest, control the fate of the water. The morphology of the vegetation can influence the quantity and distribution of water descending from the canopy to the ground surface (Schroth et al. 1999). Crown area is a significant factor in predicting variability in stemflow (Lawson 1967; Aboal et al. 1999). Matsubayashi et al. (1995) studied broadleaf trees and found that stemflow was concentrated in a 6-cm-wide band around the tree. Using this narrow area to 
determine the unit depth of stemflow revealed that stemflow was being delivered at a rate 22 times that of rainfall .Based on trunk projected area $1.5 \mathrm{~m}$ above ground, Durocher (1990) found that rainfall input at the base of some trees was 30 to 40 times larger than the mean throughfall. Essentially, throughfall is distributed over a very large area while stemflow is not.

Cape et al. (1991) conducted a study in a forest in northern Britain consisting of Pine (Pinus sylvestris L.), Norway spruce (Picea abies (L.) Karst), Sitka spruce (Picea sitchensis (Bong.) Carrière), larch (Larix decidua L.), Oak (Quercus petraea Matt.), and Alder (Alnus subcordata (L.) Gaerta). They concluded that the branching habit of each species was the main determinant of stemflow, and also noted that the provenance of a species affects the branching habit and, therefore the stemflow of that species.

The objective of this study was (i) to compare the amount of stemflow in deciduous broadleaved trees (with and without leaves) in accordance with different growth seasons and (ii) to compare the rate of stemflow in coniferous and broadleaved trees in according to the canopy cover area.

\section{Materials \& Methods}

The study was conducted in Sonbolrood forest (Fig. 1), at the southeastern edge of the city of Savadkooh in Mazandaran province, Iran. In order to provide a beautiful landscape at the sides of the forest roads, stands of Cyprus Cupressus sempervirens var. horizontalis and Alder have been planted separately. The forest has natural stands containing Beech Fagus orientalis, Alder, Ironwood Parrotia persica and Hornbeam Carpinus betulus.

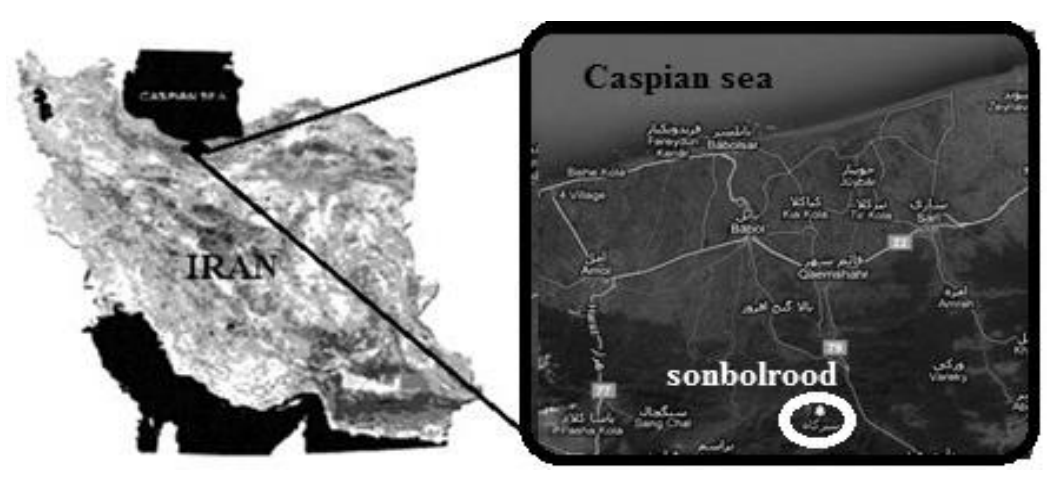

Figure 1: Map and geographical location of the study area

In order to measure the stemflow, firstly 20 trees of each species were randomly selected and then marked with spray paint. For each of the marked trees, the rate of stemflow was measured (in litres) during one hour of rainfall using a stemflow collector (Fig. 2) designed as a bucket, water-collecting gutter, pipe, black gum and tape. Tape is attached around the bark of the tree trunk using black gum, so that there are no gaps or holes. Then the edge of the water collector gutter is placed beneath the tape and fixed using gum and pins. The collected water from the outlet of the gutter is transmitted to the collection bucket through the pipe. On a sampling day, the rainfall was measured by the Synoptic station of Allasht; on average this was $3.2 \mathrm{~cm}$.

In order to investigate the role of crown area on the rate of stemflow, the minimum and maximum radius of the crown on the ground was measured in field surveys, and the crown area calculated. The collected data were analysed using ANOVA implemented in SPSS. 


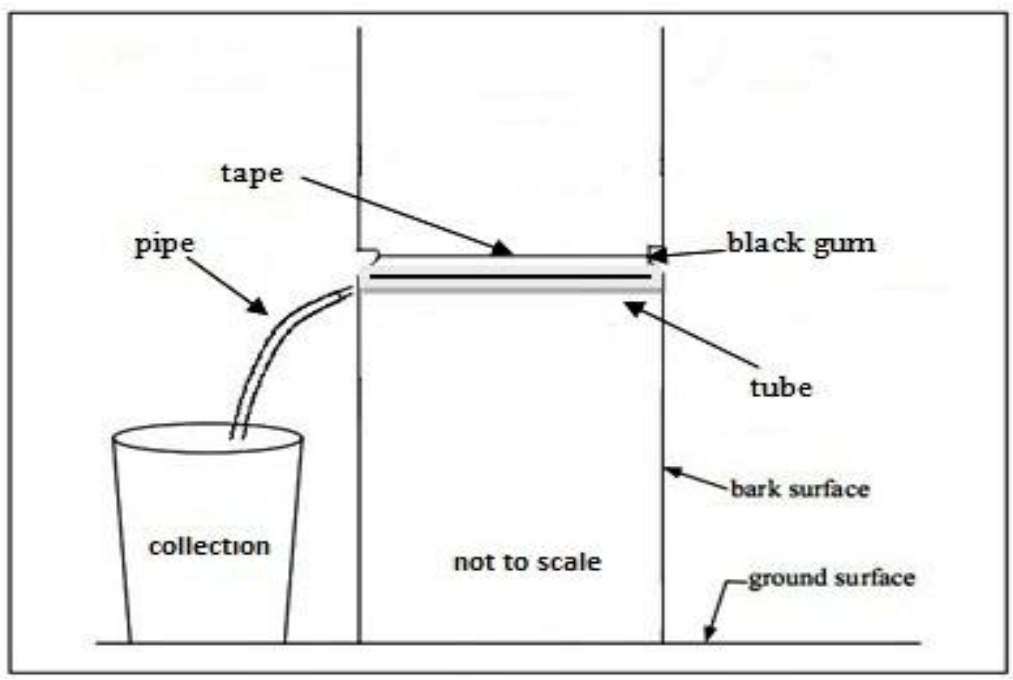

Figure 2: Measurement method of stemflow and typical stemflow collector

\section{Results}

Results show that trees with leaves in autumn have rates of stemflow that are significantly greater than in winter, when they lack leaves (Table 1). This ratio of the difference between autumn and winter was high in each case, but higher for Beech (4.1) than Ironwood (3.6), Alder (1.7) or Hornbeam (1.9). The mean of the absolute value of the stemflow for Beech was 2 to 4 times more than that of the other broadleaf species. When the data for individual trees are ranked by crown area, it is clear that the lack of leaves causes irregularities in the rate of stemflow (Fig. 3).

Table 1: ANOVA table for statistical comparsion of stemflow rates in the two different seasons of autumn and winter in four different tree species.

\begin{tabular}{ccccccc}
\hline Treatment & & DF & SS & MS & F & sig \\
\hline Fagus orientalis & season & 1 & 99.2 & 99.2 & 150.3 & $<0.001$ \\
& error & 38 & 25.08 & 0.66 & & \\
Parrotia persica & season & 1 & 49.95 & 49.95 & 70.7 & $<0.001$ \\
& error & 38 & 26.83 & 0.7 & & \\
\multirow{2}{*}{ Alnus subcordata } & season & 1 & 16.4 & 16.4 & 41.0 & $<0.001$ \\
& error & 38 & 15.15 & 0.4 & & \\
Carpinus betulus & season & 1 & 27.9 & 27.9 & 59.1 & $<0.001$ \\
& error & 38 & 17.93 & 0.47 & & \\
\hline
\end{tabular}

The results of the investigation about the effect of tree crown area on the rate of stemflow indicated that stemflow increased with increasing canopy cover area. There was a linear relationship between crown area and the rate of stemflow in Beech $\left(\mathrm{R}^{2}=0.90\right)$, but clearly non-linear relationships in Alder $\left(R^{2}=0.74\right)$, Ironwood $\left(R^{2}=0.92\right)$ and Hornbeam $\left(\mathrm{R}^{2}=0.90\right)$ (Fig. 4).

There were statistically significant differences in the average stemflow rates among tree species (Table 3). From a post-hoc multiple-range test (Table 4), the mean stemflow rate in Beech was greater than in Ironwood, which in turn was greater than the other two trees (which were not significantly different from each other). 

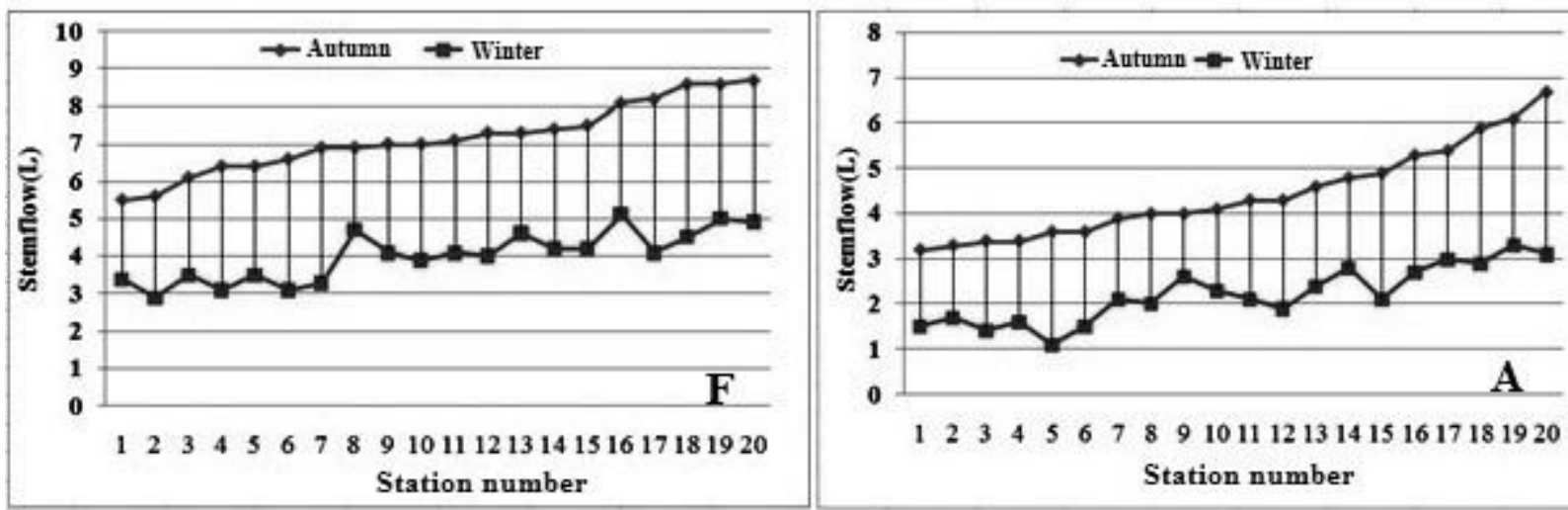

$123 \quad 3 \quad 4 \quad 5 \quad 678891011121314151617181920$ Station number

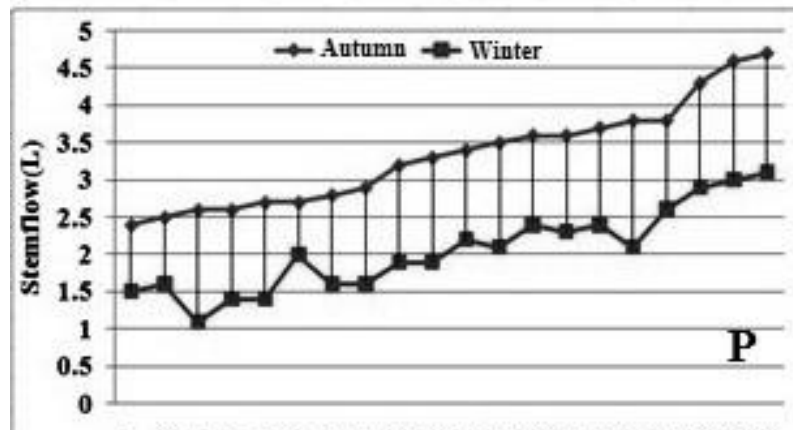

$1253456 \quad 678991011121314151617181920$ Station number

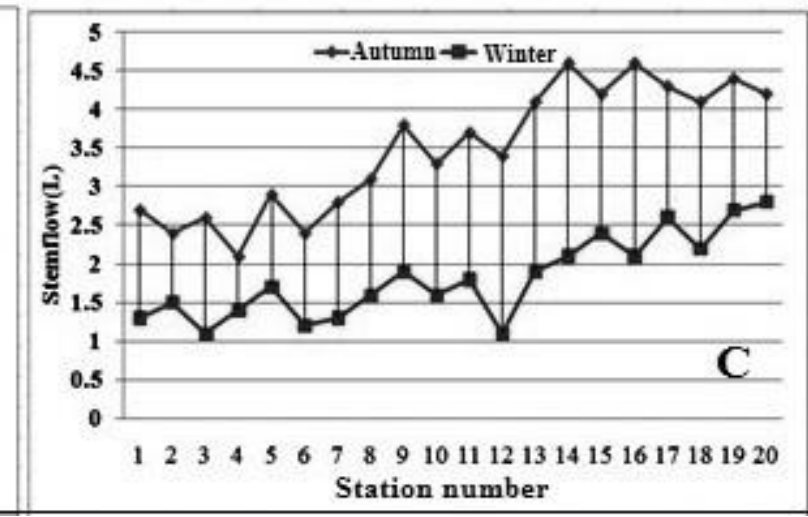

Figure 3: Comparison of stemflow rates $\left(1 \mathrm{hr}^{-1}\right)$ in different seasons of 20 individual trees, ranked by crown area. $\mathrm{F}=$ Beech Fagus orientalis $; \mathrm{A}=$ Alder Alnus subcordata $; \mathrm{P}=$ Ironwood Parrotia persica $; \mathrm{C}=$ Hornbeam Carpinus betulus

Table 2: ANOVA comparing rates of stemflow in different tree species

\begin{tabular}{|cccccc}
\hline & SS & df & M S & F & Sig \\
\hline among trees & 188.45 & 3 & 62.81 & 82.8 & $<0.001$ \\
error & 57.6 & 76 & 0.76 & & \\
\hline
\end{tabular}

Table 3: Differences in the mean rates of stemflow for different tree species, from the post hoc Duncan's multiple-range test after the Anova of Table 2.

\begin{tabular}{|c|c|c|c|c|}
\hline Data $\quad$ Litter type & Fagus orientalis & Parrotia persica & $\begin{array}{c}\text { Alnus } \\
\text { subcordata }\end{array}$ & Carpinus betulus \\
\hline Stemflow $\left(1 \mathrm{hr}^{-1}\right)$ & $7.16^{\mathrm{a}}$ & $4.44^{b}$ & $3.48^{\mathrm{c}}$ & $3.33^{\mathrm{c}}$ \\
\hline
\end{tabular}

Note: mean values with different letters are significantly different at the 0.05 probability level 

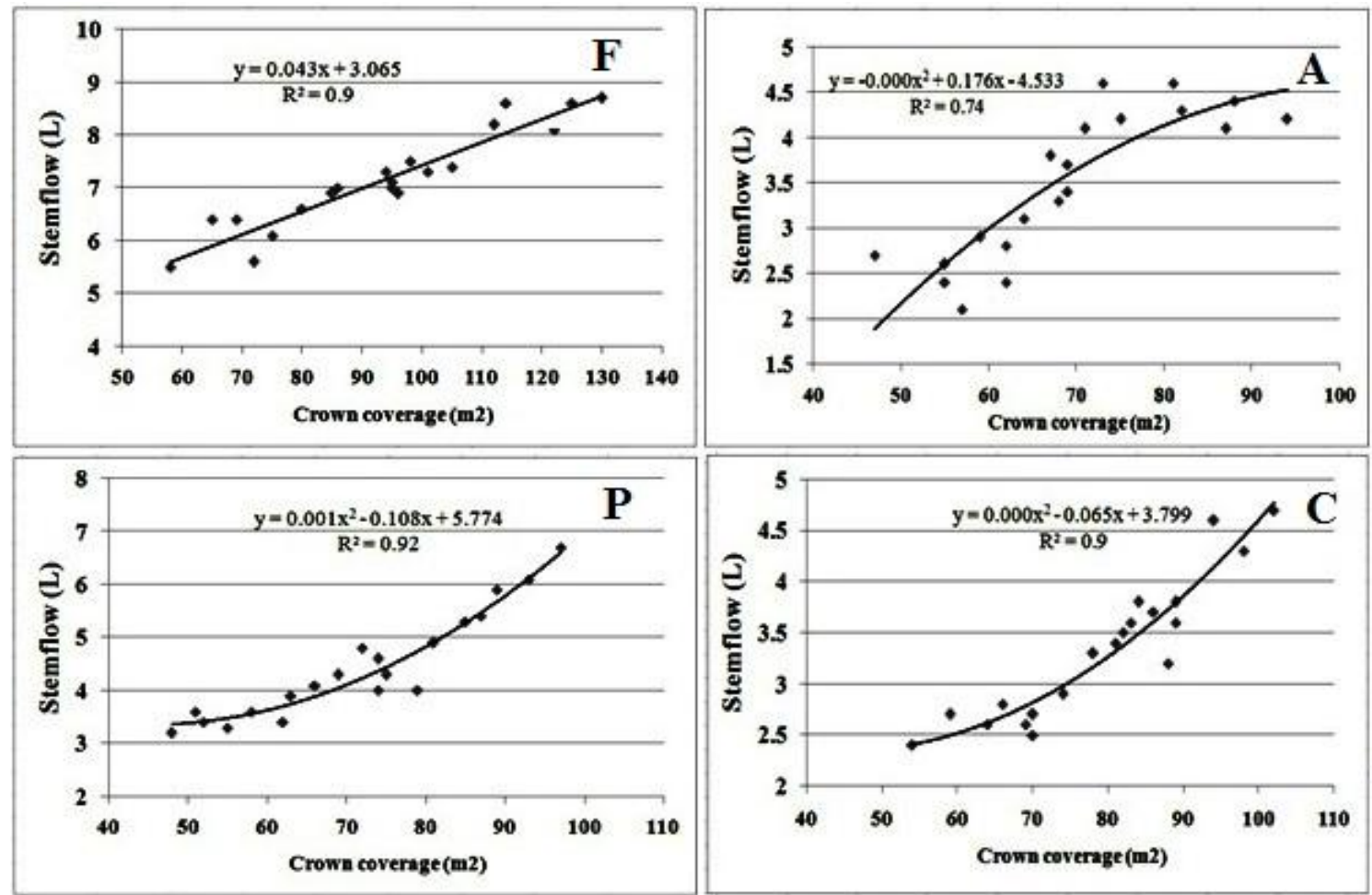

Figure 4: Relationship between crown coverage $\left(\mathrm{m}^{2}\right)$ and the rate of stemflow $\left(1 \mathrm{hr}^{-1}\right)$ in different tree species, $\mathrm{F}=$ Beech Fagus orientalis ; A = Alder Alnus subcordata; $\mathrm{P}=$ Ironwood Parrotia persica $; \mathrm{C}=$ Hornbeam Carpinus betulus

Results of the comparison between broad-leaved and coniferous trees (Table 5) showed that rates were very high in Cyprus conifers despite their low canopy cover. In Cyprus trees with canopies greater than $40 \mathrm{~m}^{2}$, the stemflow rates were more than $71 \mathrm{hr}-1$, a rate not achieved by broad-leaved species unless their canopy cover was greater than $100 \mathrm{~m}^{2}$.
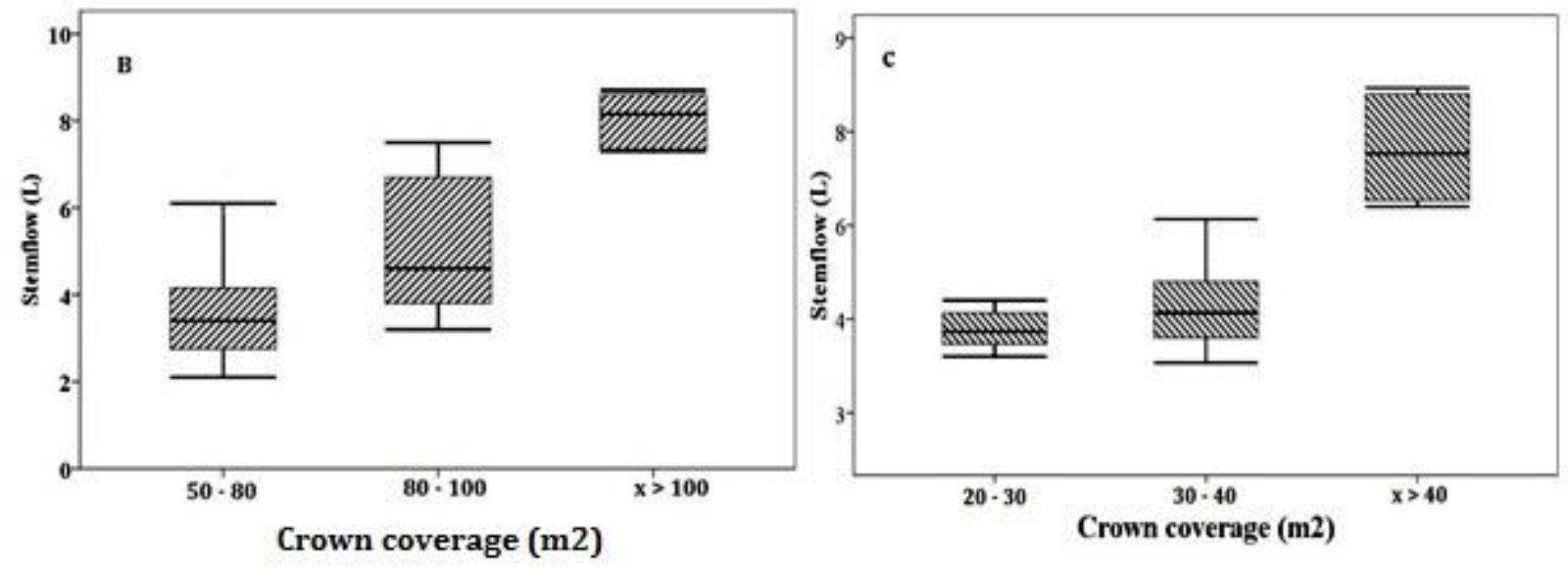

Figure 5: Comparison of stemflow in different class of crown coverage; $\mathrm{B}=$ broadleaved trees (four species); $\mathrm{C}=$ Conifers (Cyprus) 


\section{Discussion}

Hyrcanian forests stretch from sea level up to an altitude of $2800 \mathrm{~m}$, encompassing various forest types that contain a total of 80 woody species (trees and shrubs). The area is rich in hardwood species, but there are only four kinds of native softwood trees: Taxus, Juniperus, Thuja and Cupressus. From a forest geography point of view, the northern forests of Iran are classified as deciduous broad-leaved forests rather similar to Mediterranean forests (Mohajer, 2007). In these northern forests of Iran the leaves of hardwood trees fall in winter in response to temperature decreases. The lack of leaves decreases the interception of rain by trees, and increases the throughput (Xiao et al. 2000). In forest stands with dense canopies, the rate of interception is very high in summer, reaching $100 \%$ when the rain starts (Alizadeh 2007). In study area, the widespread canopy cover of beech and the strong light competition among individual trees increases the rate of rain interception.

Beech has simple, smooth and rippled leaves (Fig. 6). Observations during this study demonstrated that the ripples collect water on the ends of the leaves. In most cases this water drips in large drops onto the trunk and to the ground. The leaves of Parrotia persica are oval and arranged alternately on the branches (Fig. 6). The tree does not grow tall, but has a wide canopy. The alternate leaves and the shape of the crown increase interception, but because canopy cover is low compared to beech, the interception and stemflow is less. The shape of crown in Carpinus betulus and Alnus subcordata is irregular and less dense and widespreading in forest stands. The main reason for this is the tall growth of these trees. Species which have more crown area can provide more stemflow. When lacking leaves in winter, this process is irregular and the effects of crown area seem to be less.
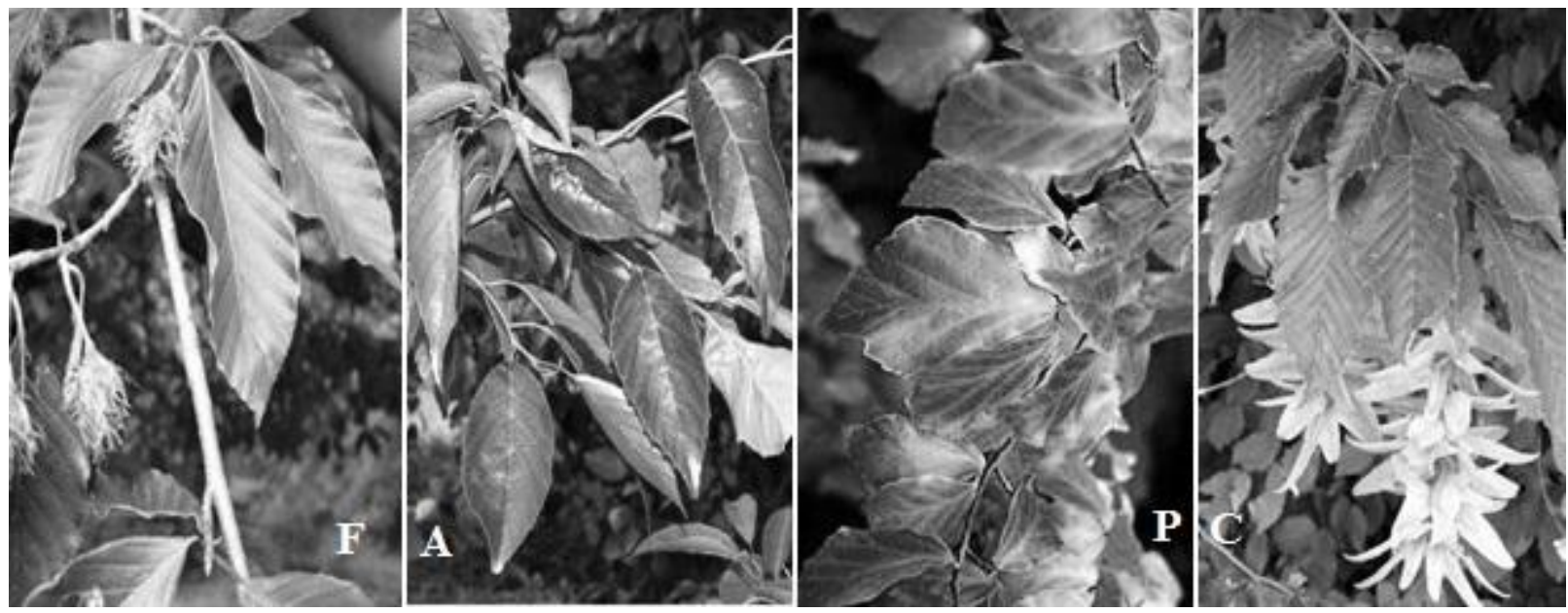

Figure 6: Leaves of the studied broad-leaved trees; F = Beech Fagus orientalis ; A = Alder Alnus subcordata ; P = Ironwood Parrotia persica ; C = Hornbeam Carpinus betulus

A further significant factor in rain interception is the nature of the bark (Helvey \& Patric 1965) (Fig. 7). The bark of trees such as Parrotia persica and Fagus orientalis conduct stemflow in a very suitable manner with minimum loss. In Carpinus betulus and Alnus subcordata, a large proportion of the stemflow is collected in the bark of the trunk and cannot reach the ground. The main reason for this is the ragged and unsmooth condition of the bark and leaves of these species. The existence of epiphytic plants which use the trunk of these trees for reach sunlight (especially Carpinus betulus) prevents stemflow reaching to the trunk. In addition, parameters of the structure of the tree crown, such as the angle of the branches and the number of trunks, have significant effects on stemflow volumes. 


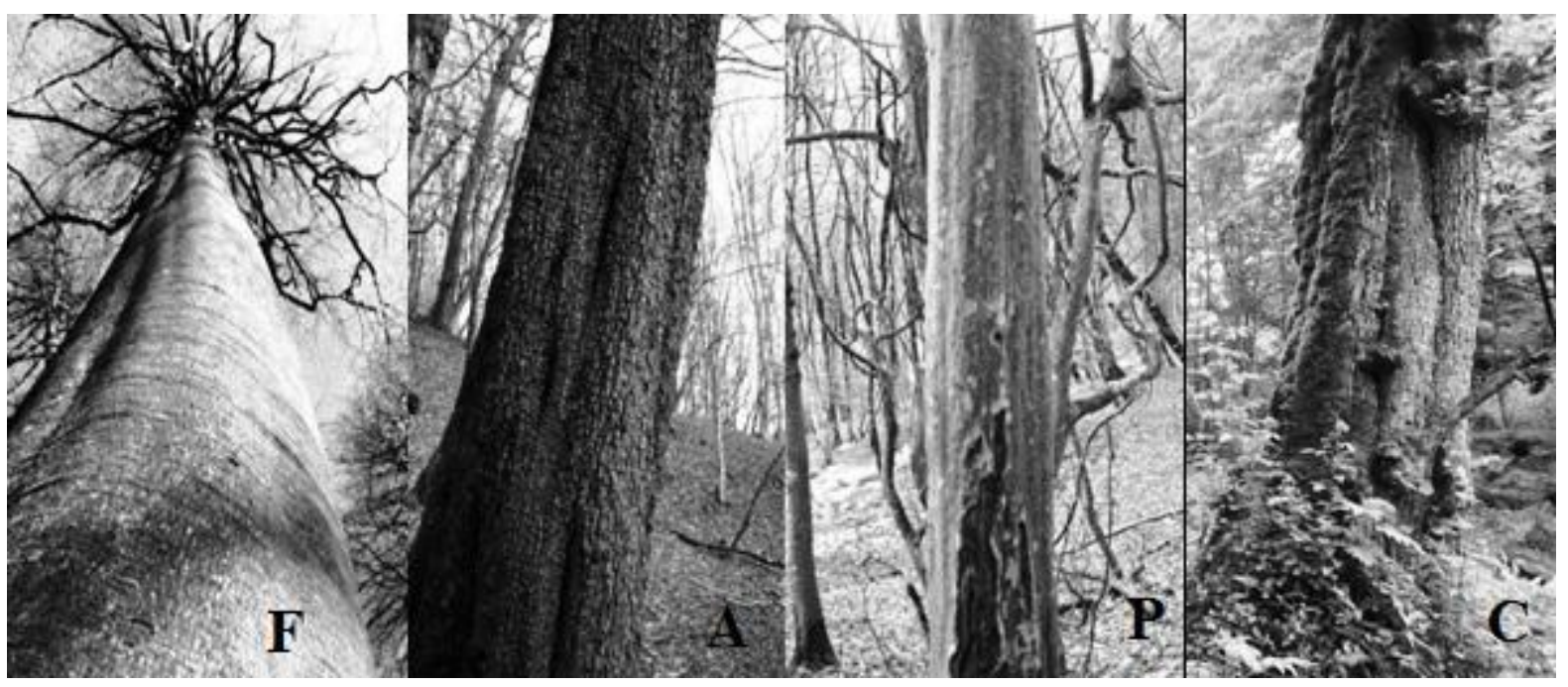

Figure 7: $\quad$ Trunk of broad-leaved trees; $\mathrm{F}=$ Beech Fagus orientalis $; \mathrm{A}=$ Alder Alnus subcordata $; \mathrm{P}=$ Ironwood Parrotia persica $; \mathrm{C}=$ Hornbeam Carpinus betulus

Horizontal branches of the tree crown causes drops to fall from branches, preventing the production of stemflow. In trees that can have multiple trunks (Parrotia persica) the probability of stemflow production is high. In spite of their relatively low canopy cover, Cupressus sempervirens have a very high rate of interception, mainly because of their dense canopy and the needle-like leaves. The water absorbed by the trunk of these trees produced high rates of stemflow in our study area. In most conifers the crown is cone-shaped and the angle of the cone has significant effects on the rate of interception. It seems that in cypresses the rate of stemflow is less than that of other conifers because of the existence of horizontal branches.

\section{Acknowledgements}

The authors would like to thank the National Foundation of Elites for funding this study. Special thanks go to Dr Smaeilzade, Mr Ahmadi, Mr Habibi and Mr Amani for their technical support throughout the course of this research project.

\section{References}

Aboal JR, Morales D, Hernandez M \& Jimenez MS (1999) The measurement and modeling of the variation of stemflow in a laurel forest in Tenerife, Canary Islands. Journal of Hydrology 221: 161-175

Alizadeh A (2007) Applied hydrology, Ferdowsi University of Mashhad. Ghods Razavi Publications, 800 pp.

Cape JN, Brown AHF, Robertson SMC, Howson G \& Paterson IS (1991) Interspecies comparisons of throughfall and stemflow at three sites in northern Britain. Forest Ecology \& Management 46: 165-177

Durocher MG (1990) Monitoring spatial varability of forest interception. Hydrological Processes 4: 215-229

Ebrahimpour KJ, Nemati M \& Samariha A (2011) Study of product of the wood in forests in North of Iran at ten years period. Journal of Basic \& Applied Scientific Research 1(9): 1255-1261

Hanchi A, Rapp M (1997) Stemflow determination in forest stands. Forest Ecology \& Management 97: 231-235

Helvey JD, Patric JH (1965) Canopy litter and interception of rainfall by hardwoods of Eastern United States. Water Resources Research 1: 193-206

Lawson E (1967) Throughfall and stemflow in a pine-hardwood stand in the Ouachita Mountains of Arkansas. Water Resources Research 3: 731-735

Matsubayashi U, Velasquez GT, Sasuga H, Sumi T \& Takagi F (1995) On the physical and chemical properties of throughfall and stemflow. Journal of Hydroscience \& Hydraulic Engineering 13: 69-81.

Mohajer M R (2007) Silviculture, University of Tehran, No 2709, 387 pp.

Schroth G, da Silva LF, Wolf MA, Teixeira WG \& Zech W (1999) Distribution of throughfall and stemflow in multi-strata agroforestry, perennial monoculture, fallow and primary forest in central Amazonia, Brazil. Hydrological Processes 13: 1423- 1436

Xiao Q, McPherson EG, Ustin SL, Grismer ME \& Simpson JR (2000) Winter rainfall interception by two mature open-grown trees in Davis, California. Hydrological Processes 14: 763-784 


$$
\begin{aligned}
& \text { الملخص العربي } \\
& \text { دراسة العوامل المؤثرة على انسياب السوائل بسيقان الأثجار فى غابات هيركانيان - إيران } \\
& \text { ميهران ناصيرى - ناستاران زارى - حامد جاليلفاتد }
\end{aligned}
$$

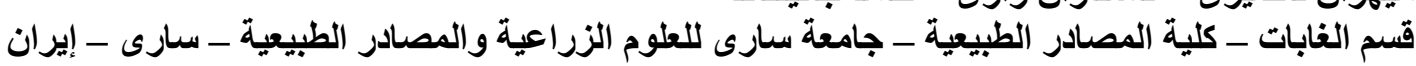

إن الهـف من هذه الدراسة هو مقارنة كمية انسياب السوائل فى سيقان الأشجار ذات الأوراق العريضة (التى لها أوراق

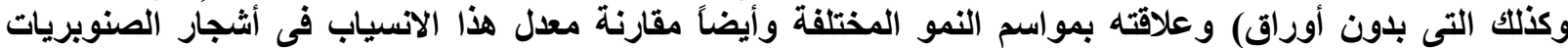

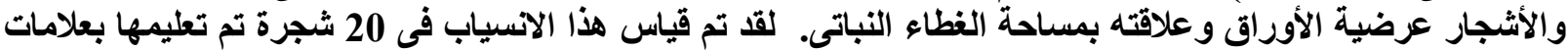

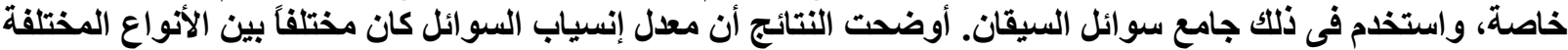

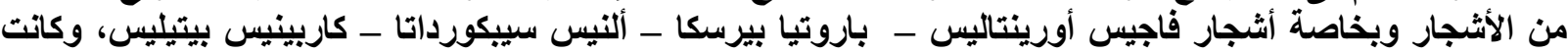

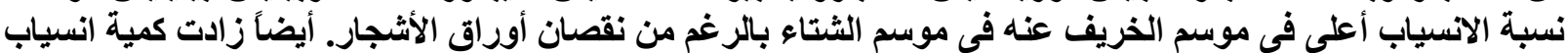

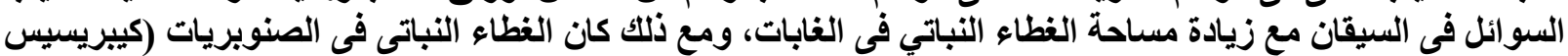

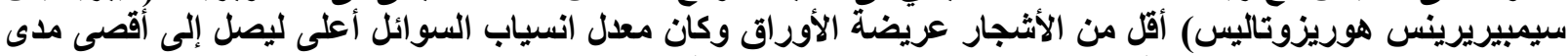

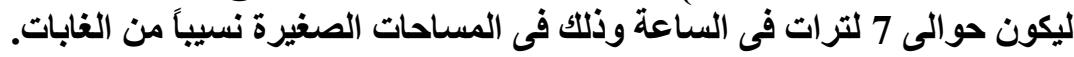

